Bożena Hojka

https://doi.org.10.26881/ae.2018.15.06

ORCID: 0000-0002-4591-4346

Uniwersytet Wrocławski

Instytut Informacji Naukowej i Bibliotekoznawstwa

bozena.hojka@uwr.edu.pl

\title{
Język i kultura w obrazkach - o problematyce badawczej obrazkowych słowników dla dzieci w kontekście kulturowym ${ }^{1}$
}

\section{Słownik a kultura - założenia i cel pracy}

Nasze codzienne życie w dużej mierze toczy się w świecie słów - to nimi posługujemy się, by nawiązywać relacje z ludźmi, interpretować otaczającą nas rzeczywistość, wyrażać swój stosunek do tego, czego doświadczamy. A nawet - czego kwintesencją jest literatura - by tworzyć werbalne substytuty świata, doświadczenia i przeżyć. Język to nie zbiór etykiet, którymi opatrujemy byty. Jest czymś zdecydowanie ważniejszym - utrwala określony obraz świata, podsuwa wybrane sposoby konceptualizacji, przekazuje wreszcie - poprzez tkwiące w nim konotacje i stereotypy - potoczną wiedzę i przekonania gromadzone od pokoleń. Lingwistyka kulturowa, inspirowana między innymi poglądami badaczy kultury Edwarda Sapira i Banjamina Lee Whorfa (zob. Siemieński 1991), dostrzega w języku klucz do zrozumienia kultury określonej społeczności. Janusz Anusiewicz, inicjator i propagator programu polskich badań nad relacją między językiem a kulturą pisał: „Język jest traktowany jako jej [kultury - B.H.] warunek wstępny, implikator, składnik, rezerwuar, "pas transmisyjny» oraz interpretator i interpretant zawierający najistotniejsze treści kultury” (Anusiewicz 1994: 10; zob. też idem 1991). Dlatego przyswajanie języka to nie tylko nabywanie kompetencji komunikacyjnych. To także rozwijanie systemu poznawczego i wrastanie w określoną, ściśle z tym językiem związaną

${ }^{1}$ Tekst jest poszerzoną wersją referatu wygłoszonego 8 grudnia 2017 roku w Gdańsku podczas ogólnopolskiej konferencji naukowej „W interakcji słów i obrazów” zorganizowanej przez Instytut Pedagogiki Uniwersytetu Gdańskiego, Pracownię Interdyscyplinarnych Badań Książki Obrazkowej przy UG oraz Nadbałtyckie Centrum Kultury w Gdańsku. 
kulturę. A poznawanie obcego języka to jednocześnie nauka odmiennego (mniej lub bardziej) sposobu patrzenia na świat i poznawanie innej kultury.

$\mathrm{Z}$ tej perspektywy słownik - rozumiany jako opis zasobu leksykalnego danego języka lub języków ${ }^{2}$ - jawi się jako potencjalny obiekt zainteresowania nie tylko językoznawców, ale także badaczy kultury. I to na dwóch poziomach. Po pierwsze: „opis słownictwa od strony znaczeniowej jest jednocześnie opisem kultury, ponieważ słownictwo można traktować jako zbiór znaków odnoszących się do tych aspektów kultury, które dana społeczność traktuje jako stabilne i ważne dla jej funkcjonowania. Wyrazy kodują te doświadczenia lub obiekty, które są intersubiektywnie postrzegane jako ważne dla członków danej kultury. [...] Słownictwo jest w pewnym sensie opisem świata danej społeczności, a słownik można nazwać swoistym przewodnikiem po tym świecie" (Piotrowski 1993: 572). Po drugie - jak słusznie zauważa dalej Tadeusz Piotrowski - słownik porządkuje i opisuje wyrazy $\mathrm{w}$ określony, nigdy neutralny sposób, a przesłanki kulturowe odgrywają $\mathrm{w}$ tym wypadku bardzo ważną rolę: „Ponieważ słownictwo można traktować jako zbiór nazw faktów kulturowych, wszelkie operacje dokonywane w słowniku można utożsamiać z manipulacją faktami kulturowymi" (ibidem: 572-573).

Przyjmując powyższe założenie, chciałabym przyjrzeć się szczególnej operacji dokonywanej w słownikach obrazkowych dla dzieci. Mam na myśli prezentowanie znaczenia słów w formie ilustracji. Taki ikonograficzny sposób zaznajamiania z semantyką słowa jest od dawna znany z praktyki leksykograficznej, jest również przedmiotem zainteresowania badaczy (zob. Hupka 1989; Szczepaniak 2000; Hojka 2008; Kwaśnicka-Janowicz 2008; Biesaga 2016; Lew et al. 2017). Badany jest jednak przede wszystkim w odniesieniu do słowników adresowanych do dorosłych odbiorców, najczęściej pedagogicznych, czyli służących nauce języka obcego, i w tym kontekście najczęściej rozpatrywany.

Słowniki dla dzieci, chociaż pełnią podobne funkcje jak słowniki dla dorosłych, a więc służą kształtowaniu różnorodnych kompetencji językowych, rządzą się własnymi prawami, dlatego też wymagają odrębnych badań. Niestety są najczęściej pomijane (poza krótkimi wzmiankami) zarówno w refleksji nad książką edukacyjną, jak i w rozważaniach o książce ilustrowanej i obrazkowej - a niezaprzeczalnie do obu tych kategorii należą. Jednocześnie jest to typ książki dziecięcej bardzo obszernie reprezentowany na polskim rynku wydawniczym i do tego podlegający współcześnie intensywnym przemianom. Specyficzny, dziecięcy odbiorca wpływa nie tylko na zawartość treściową i założone funkcje słownika, ale także na ukształtowanie edytorskie tego rodzaju publikacji. Wszystko to otwiera pole dla wielorakich analiz i różnorodnych perspektyw - począwszy od językoznawczej i glottodydaktycznej, poprzez bibliologiczną, edytorską, aż po pedagogiczną, kulturoznawczą i socjologiczną. Również ilustracja w słowniku dla dzieci - zarówno jej formy, treść, jak i funkcje - wymaga odrębnego opracowania. Niniejszy artykuł jest próbą

\footnotetext{
${ }^{2}$ „Słownik można zdefiniować jako uporządkowany zbiór słownictwa jednego lub więcej niż jednego języka" (Piotrowski 1993: 571)
} 
nakreślenia - na podstawie prowadzonych badań własnych - jednego z obszarów takiej refleksji. Moim nadrzędnym celem jest wskazanie wybranych problemów badawczych związanych $\mathrm{z}$ kulturowym kontekstem ilustrowania słowników dla dzieci.

\section{Słownik obrazkowy dla dzieci a książka obrazkowa}

Refleksję nad kulturowymi aspektami ilustracji słownikowej dla dzieci warto poprzedzić próbą przyjrzenia się jej roli w tego typu publikacjach i relacji, która łączy ją z tekstem. W słownikach dla młodych odbiorców kolorowe ilustracje są niemal obligatoryjnym elementem wyposażenia edytorskiego, ale też - co istotniejsze - integralną częścią ich treści. W zasadzie można postawić znak równości między słownikiem dla dzieci a słownikiem ilustrowanym bądź obrazkowym - obraz i kolor pojawiają się w nim niemal zawsze, niezależnie od reprezentowanego typu. W słowniku ilustrowanym grafiki towarzyszą objaśnieniom słownym (definicjom, ekwiwalentom itd.), są elementem w stosunku do nich uzupełniającym, dodatkowym. W słownikach obrazkowych są natomiast główną (i często jedyną) formą prezentowania słownictwa i jego znaczenia, zastępują zatem słowne definicje i objaśnienia.

W niniejszym tekście to właśnie słowniki obrazkowe - ze względu na szczególną rolę, jaką odgrywają $\mathrm{w}$ nich ilustracje - są przedmiotem mojego zainteresowania. W tego typu słownikach kod językowy i obrazowy są równorzędne, a ich współdziałanie konieczne, by słownik spełniał swoje poznawcze i edukacyjne zadania. Warstwa tekstowa to słowa, leksemy, ewentualnie wyrażenia i zwroty (wyjątkowo tylko teksty), warstwa wizualna to wizerunki ich desygnatów, w różnych ujęciach i formach. Można zatem powiedzieć, że podstawowa treść słownika obrazkowego (a więc wiedza o znaczeniu i użyciu słów) konstytuuje się w interakcji między słowem (lub zwrotem, wyrażeniem językowym) a obrazem (wizualnym przedstawieniem jego znaczenia). Usunięcie któregokolwiek z tych elementów de facto pozbawia słownik jego najważniejszej treści i jednocześnie funkcji - słownik przestaje być słownikiem. Pozbawiony warstwy obrazowej staje się wykazem słów, pozbawiony słów jest jedynie zbiorem obrazków. Wydaje się, że w związku z tym można mówić o polisemiotycznym charakterze treści słowników obrazkowych, wynikającym ze współdziałania słowa i towarzyszącego mu przedstawienia obrazowego. Nasuwa się zatem pytanie, czy słowniki obrazkowe można uznać za typ książki obrazkowej i tym samym podczas ich analizy korzystać z metod i narzędzi wypracowywanych w obrębie bardzo intensywnie się dziś rozwijających badań nad książką obrazkową.

Trudność $\mathrm{z}$ odpowiedzią na to pytanie wiąże się tak naprawdę z brakiem jednoznacznej i powszechnie akceptowanej definicji książki obrazkowej (zob. Cackowska 2010). Jeśli jednak przyjąć, zgodnie z tym, co pisze Małgorzata Cackowska, że „Pośród badaczy zasadniczo istnieje zgoda $\mathrm{w}$ sprawie pojmowania książki obrazkowej jako tej, która jest złożona z dwu sposobów przedstawiania, dwu reprezentacji - obrazów 
i słów - stanowiących tekst kulturowy" (Cackowska 2017: 11), i pominąć bardziej szczegółowe kryteria formułowane w stosunku do książek obrazkowych - odpowiedź powinna być twierdząca. Z pewnością mamy w słownikach obrazkowych do czynienia z relacją obrazu i tekstu oraz współdziałaniem tych dwóch systemów semiotycznych w tworzeniu treści komunikatu, co z kolei pozwala przywołać zaproponowane przez Kristin Hallberg pojęcie ikonotekstu (Hallberg 2017: 52). Warto zatem przyjrzeć się bliżej relacjom między obrazem a tekstem w różnego rodzaju słownikach obrazkowych i podjąć próbę ewentualnego usytuowania ich w obrębie kategorii książek obrazkowych. Poza oczywistą relacją definiowania (obraz definiuje znaczenie słowa) możemy bowiem dostrzec $\mathrm{w}$ różnych słownikach dodatkowe zależności i funkcje warstwy ikonograficznej.

Szczególnie wyjątkową rolę odgrywa obraz w słownikach przeznaczonych dla najmłodszych użytkowników. Rozbudowana warstwa ilustracyjna staje się w nich nadrzędnym, dominującym nośnikiem treści. To przede wszystkim ona jest dostępna percepcji dziecka i oddziałuje na nie poznawczo, estetycznie i emocjonalnie. Towarzyszący obrazom zapis nazw ma natomiast oswajać dziecko z ich formą graficzną i tworzyć skojarzenie między nią a prezentowanym obiektem. Oczywista jest przy tym zależność, że im młodszy adresat, tym warstwa obrazowa odgrywa ważniejszą rolę. W wypadku książeczek dla dzieci w wieku przedczytelniczym (nieumiejących czytać) zasadne staje się wręcz pytanie o to, czy mamy w ogóle do czynienia ze słownikiem, skoro jest to książka „do oglądania”. Takie parasłowniki dla najmłodszych (które w polskiej praktyce wydawniczej często w tytule określane są jednak jako „słownik”, „słowniczek”) w zasadzie są odmianą obrazkowych książek wczesnokonceptowych, które przybliżają dzieciom podstawowe pojęcia, ułatwiając tworzenie ich mentalnych reprezentacji, i jako takie powinny być badane (zob. Kümmerling-Meibauer, Meibauer 2017).

Do starszych nieco odbiorców (dzieci w wieku szkolnym) są kierowane przede wszystkim obrazkowe słowniki pedagogiczne (służące nauce języka obcego). One z kolei swoim graficznym ukształtowaniem bardzo często przywodzą na myśl obrazkowe książki pokazywanki - ze względu na sceniczne ilustracje (odwołuję się tu do typologii ilustracji słownikowych zaproponowanej w: Hupka 1989). Pojawiają się w nich bogate w szczegóły przedstawienia sytuacyjne, całe scenki rodzajowe, które często mają wspólnych bohaterów. Kolejne ilustracje stanowią zazwyczaj odrębne, autonomiczne treściowo całości, zdarzają się jednak i takie realizacje, w których są one powiązane i zawierają elementy fabuły. Dodatkowym niejako elementem są (decydujące o „słownikowości” publikacji) podpisy obiektów pojawiające się bezpośrednio na ilustracji lub obok niej. Warstwa obrazowa może być percypowana autonomicznie, dopiero jednak w interakcji z zamieszczonymi na ilustracjach podpisami (leksemami) może funkcjonować jako publikacja wspomagająca nabywanie umiejętności językowych, a więc słownik.

$\mathrm{Na}$ rynku istnieją wreszcie przykłady dziecięcych słowników, które w zasadzie można zaliczyć do książek obrazkowych narracyjnych. Ilustracje, na których poszczególne elementy są wskazywane i podpisywane odpowiednim leksemem, 
dopełniają ujętą w krótki tekst narrację, współtworząc wraz z nią fabułę. Między tekstem a obrazem mamy zatem do czynienia z relacją charakterystyczną dla narracyjnych książek obrazkowych, a interakcja obrazu z nazwami obiektów tworzy słownikową treść. Tego typu publikacje są jednak zdecydowanie wyjątkiem potwierdzającym nienarracyjny charakter słowników obrazkowych.

Omówione powyżej trzy przykłady sygnalizują pierwszy kompleks zagadnień badawczych związanych ze słownikami dla dzieci, który obejmuje konieczność wyodrębnienia tej kategorii publikacji i wskazania jej wyznaczników, opracowanie typologii słowników dla dzieci i uporządkowanie tej bardzo różnorodnej grupy książek dziecięcych. Zadania tego nie ułatwia zamęt terminologiczny widoczny w tytułach tego typu wydawnictw (słownik, leksykon, encyklopedia, abecedariusz, słówka, słowa - często z określeniami typu „moje”, „pierwsze”). Obecne na współczesnym rynku słowniki podlegają ponadto bardzo intensywnym przemianom $\mathrm{w}$ zakresie modelu edytorskiego i funkcji. Można wręcz mówić o ich hybrydyzacji czy też synkretyzmie. To wszystko sprawia, że badając i próbując opisać współczesne słowniki dla dzieci, należy uwzględniać ich wyraźne powiązania z takimi typami publikacji edukacyjnych jak podręcznik, zeszyt ćwiczeń (activity book), encyklopedia czy książka-zabawka. I to nie tylko w zakresie formy wydawniczej, ale również treści i zakresu przekazywanej przez nie wiedzy oraz funkcji edukacyjnych. Ze względu na specyficzną rolę obrazu i jego ścisłą interakcję z przekazem językowym bardzo istotnym pokrewieństwem wydaje się jednak także to łączące słowniki obrazkowe z książkami obrazkowymi.

\section{Ilustracje w słownikach obrazkowych - założenia, funkcje, formy}

Bardzo istotny obszar zagadnień badawczych związanych z funkcjonowaniem ilustracji w słownikach obrazkowych dla dzieci wyznacza perspektywa leksykograficzna. Jednym $\mathrm{z}$ najważniejszych problemów jest $\mathrm{w}$ tym wypadku odpowiedź na pytanie, czy ilustracje w słownikach dla dzieci muszą spełniać kryteria, które formułuje się wobec ilustracji słownikowej rozumianej jako typ definicji (definicja ikonograficzna, zob. na ten temat: Hojka 2008). Czy powinna być ona zgodna z przyjętą metodologią i odzwierciedlać stan teorii semantycznych? I jak wygląda $z$ tego punktu widzenia współczesna praktyka? Już pobieżna analiza dostępnych na polskim rynku słowników dla dzieci pozwala stwierdzić, że zazwyczaj tak nie jest. Ilustracje w słownikach dla dzieci często nie spełniają nawet najbardziej podstawowego wymogu, aby prezentować na nich obiekty najbardziej typowe, będące niejako prototypowymi przedstawicielami kategorii odpowiadających poszczególnym leksemom. Wynika to zapewne z faktu, że słowniki dla dzieci nie są tworzone przez leksykografów, a o treści i formie ilustracji decydują raczej projektowane upodobania dziecięcego adresata, nie zaś przyjęta koncepcja objaśniania znaczenia. Jakie zatem założenia przyświecają twórcom słowników ilustrowanych? Z opisów i tekstów 
promocyjnych przygotowywanych przez samych wydawców wynika, że ilustracje w słowniku dziecięcym są postrzegane przede wszystkim jako element wpływający na atrakcyjność wizualną publikacji i odgrywający funkcję mnemotechniczną ${ }^{3}$. Biorąc pod uwagę edukacyjny potencjał słowników dla dzieci, takie podejście uznać należy za zmarnowaną szansę. Funkcje dobrze opracowanych słowników obrazkowych właśnie za sprawą obecnego w nich obrazu nie ograniczają się do podnoszenia kompetencji językowych dziecka, ale obejmują też między innymi dostarczanie wiedzy o świecie i to w sposób poglądowy, a więc bardzo efektywny (zob. Hojka 2016), kształcenie ogólnych umiejętności kognitywnych (na przykład kategoryzowanie, tematyzowanie), rozwój kompetencji informacyjnych czy wreszcie - tak ważną we współczesnym świecie - alfabetyzację wizualną. Uwzględniając dodatkowo funkcję motywującą i aktywizującą, otrzymujemy zbiór możliwości, który czyni z właściwie opracowanej ilustracji słownikowej potężne narzędzie edukacyjne. Bardzo często niestety niedoceniane.

W kontekście powyższych spostrzeżeń bardzo interesujący jest problem fikcyjności ilustracji w słownikach dla dzieci. Wykorzystywanie w warstwie graficznej postaci, wątków i motywów znanych z literatury dziecięcej, filmów animowanych i kultury popularnej z założenia kłóci się z mimetyzmem, który powinien cechować ilustrację słownikową. Potwierdza jednocześnie sformułowaną wcześniej tezę, że ilustracje w tych publikacjach są postrzegane raczej w kontekście swojej formy graficznej niż wartości merytorycznej i edukacyjnej.

Zagadnienie graficznego kształtu ilustracji ma też swój wyraźny kontekst kulturowy - na uwagę badacza zasługują między innymi style ilustrowania słowników i ich przemiany historyczne, czynniki wpływające na ich ukształtowanie, związki z rozwojem przemysłu poligraficznego, kanonami estetycznymi czy wreszcie nurtami w ilustracji książkowej w ogóle. Zagadnienia te można oczywiście rozważać także w kontekście estetyki i wychowania estetycznego.

\section{Ilustracje w słownikach dla dzieci a transfer kultury}

Kulturowe uwarunkowania i aspekty ilustracji słownikowej najwyraźniej ujawniają się podczas próby opisu i analizy treści ilustracji zamieszczanych w słownikach obrazkowych dla dzieci. Słowniki te zazwyczaj objaśniają słownictwo z wielu pól semantycznych, a zatem $\mathrm{w}$ warstwie ilustracyjnej pojawiają się przedstawienia różnych fragmentów rzeczywistości i rozmaitych obszarów życia społecznego. Często (wyjątkiem są tu wzmiankowane słowniki nawiązujące do fikcyjnych tematów kultury dziecięcej, stanowiące najczęściej element tzw. produktu totalnego - zob. Zając 2000: 163-166) jest to odwzorowanie realnego świata.

Zasób słownictwa jest zazwyczaj ograniczony do tego, które dotyczy najbliższego otoczenia dziecka i jego bezpośrednich doświadczeń: człowiek i jego ciało,

\footnotetext{
${ }^{3}$ Zagadnienie to jest przedmiotem moich odrębnych badań.
} 
ubrania, pożywienie, rodzina, dom, przyroda, relacje międzyludzkie, emocje itp. Dobór słownictwa sam w sobie jest uwarunkowany kulturowo i cywilizacyjnie (zrelatywizowany geograficznie i historycznie), determinuje przy tym w zasadniczym zakresie treść warstwy obrazowej w tym sensie, że określa obiekty i zjawiska, których przedstawienia zaprezentowane zostaną $\mathrm{w}$ formie wizualnej.

Ilustracje słownikowe (poza pewnymi wyjątkami) nie mają charakteru fabularnego, nie opowiadają historii. Ich funkcją jest ukazanie, zaprezentowanie odpowiadających konkretnym wyrazom fragmentów otaczającego świata i rzeczywistości w jej różnorodnych aspektach (społecznym, przyrodniczym, cywilizacyjnym, kulturowym). Można dodać: rzeczywistości dziecka, bo jednym z założeń słowników dla dzieci jest, jak już wspominałam, prezentowanie słownictwa bliskiemu dziecku, a zatem i bliskich mu aspektów rzeczywistości. Oczywiście należałoby dodać: $\mathrm{w}$ ujęciu dorosłych - bo to oni słowniki tworzą i poprzez dobór prezentowanego słownictwa i treść ilustracji ujawniają niejako swoje wyobrażenie na temat tego, co jest dziecku bliskie. Słowniki dla dzieci można więc potraktować jako pośrednie świadectwo wyobrażeń danej epoki na temat dzieciństwa i dziecka oraz tego, jaką wiedzą o świecie powinno ono dysponować. Próbując za pośrednictwem słów i obrazów wprowadzać dziecko w świat, autor słownika może ukazywać ten świat takim, jakim według niego widzi go dziecko, albo wręcz przeciwnie - próbować wpłynąć na to, w jaki sposób będzie go ono widziało, pobudzać do refleksji i podsuwać określone sposoby interpretacji. Może tworzyć wizję świata bezpiecznego, oswojonego i przyjaznego lub też uwzględniać całą jego złożoność wraz z zagrożeniami i niebezpieczeństwami.

Bardzo ważnym zagadnieniem, które w związku z tym badacz słowników obrazkowych musi wziąć pod uwagę, jest zakres wiedzy kulturowej i społecznej zawartej w poszczególnych publikacjach oraz uwzględniane w nich obszary życia społecznego i kulturalnego (na przykład rodzina, szkoła, przedszkole, instytucje życia społecznego, zawody, sport itd.). Istotne jest przy tym nie tylko to, jakie pola semantyczne są prezentowane, ale też to, jaka jest ich zawartość (na przykład: jakie nazwy członków rodziny są uwzględnione, nazwy których zawodów, jakie formy aktywności sportowej itd.). Pozwala to porównywać poszczególne publikacje, a w rezultacie wskazać obszary, które w danej kulturze, w danej epoce historycznej odgrywały najważniejszą rolę i funkcjonowały jako swoista wizytówka ówczesnego świata.

Kolejne pytanie dotyczy tego, jaka wiedza pozajęzykowa jest zawarta w ilustracjach dotyczących uwzględnionych w słowniku kręgów tematycznych. Odnosi się to zwłaszcza do ilustracji sytuacyjnych i kontekstowych, które w swojej złożoności wychodzą daleko poza prezentowanie desygnatów wyrazów. Często ilustracje takie mają formę scenek rodzajowych, nierzadko bardzo szczegółowych i mocno rozbudowanych, na których są widoczne różne typowe dla członków danego społeczeństwa zachowania i czynności życia codziennego. Ilustracje tego rodzaju stanowią w pewnym sensie panoramę społeczną i kulturową, na podstawie której dziecko może tworzyć swoje wyobrażenie na temat norm i wzorców związanych z konkretnymi sytuacjami. Odrębnym, bardzo interesującym problemem jest sposób 
prezentowania obiektów i zjawisk, wybór otoczenia i kontekstu, w jakich zostaną one ukazane, ujawniane w obrazie konotacje czy nieistotne $\mathrm{z}$ językowego punktu widzenia właściwości.

To wszystko składa się na problem kulturowego nacechowania (tu i teraz) uwzględnionego $\mathrm{w}$ słowniku słownictwa, ale przede wszystkim jego graficznego ujęcia w formie ilustracji. Analiza słowników wydawanych w różnych okresach historycznych pokazuje bardzo wyraźnie, że problem aktualności treści dotyczy w dużo większym stopniu warstwy ilustracyjnej, ponieważ zasadniczo trwałe i niezmienne pojęcia są objaśniane wizerunkami obiektów, które wraz z rozwojem cywilizacyjnym ulegają bardzo istotnym przemianom.

W kontekście kulturowego nacechowania niezwykle interesująco rysuje się kwestia dostosowywania publikacji obcych do rodzimego odbiorcy. Wydawanie słowników przygotowywanych z myślą o innym rynku wydawniczym, a zatem dla odbiorcy reprezentującego odmienną kulturę, jest zjawiskiem częstym w polskiej praktyce wydawniczej. Publikacje wydawane na licencji najczęściej adaptowane są tylko w warstwie językowej, bez ingerencji w przekaz wizualny, co czyni niektóre ilustracje nieczytelnymi dla polskiego odbiorcy. Chodzi tutaj na przykład o odmienność realiów, nieznajomość pojawiającej się w ilustracjach symboliki czy odwołań do obrzędów, tradycji, świąt itd. Odmienności kulturowe pojawiają się też na głębszym, światopoglądowym poziomie. Wydawane na przykład w Polsce słowniki języka angielskiego francuskich autorów wyróżniają się na tle rodzimej produkcji odmiennym podejściem do tzw. tematów trudnych. Uwzględniane w nich i wizualizowane słownictwo odnosi się do różnorodnych problemów społecznych, negatywnych zjawisk i emocji, $\mathrm{z}$ dużo większą swobodą są $\mathrm{w}$ nich traktowane tematy tabu, jak fizjologia, śmierć, niepełnosprawność.

Powyższy przykład pokazuje bardzo wyraźnie, że treść słownika może być odzwierciedleniem społecznego podejścia do dziecka i dzieciństwa. Wiąże się z tym wiele szczegółowych zagadnień, takich jak choćby obecność w słownikach tematów tabu ${ }^{4}$, stereotypów społecznych czy wreszcie określonej ideologii. Zasadne wydaje się w związku z tym badanie treści słowników dla dzieci z perspektywy krytycznej analizy dyskursu (zob. Kopińska 2016), a wzorzec metodologiczny mogą stanowić prace dotyczące ideologii w podręcznikach do nauki języków obcych (zob. Piekot, Żurek 2008). Między niektórymi publikacjami słownikowymi kierowanymi do dzieci bardzo wyraźnie zarysowują się różnice w prezentowanej przez nie wizji świata, propagowanych normach i sposobach interpretowania rzeczywistości. Ujawnia się to $\mathrm{w}$ doborze słownictwa, a przede wszystkim $\mathrm{w}$ warstwie ilustracyjnej. Ukazany obraz rodziny, przedszkola, szkoły, relacji międzyludzkich itp. może odzwierciedlać aktualne modele życia społecznego, utrwalone stereotypy społeczne, powielane

${ }^{4}$ Referat poświęcony temu zagadnieniu wygłosiłam w 2017 roku podczas II Międzynarodowej Konferencji „Badania porównawcze nad językiem i kulturą - brudne, odrażające, niechciane” zorganizowanej w Poznaniu 18-19 września przez Zakład Badań Porównawczych nad Kulturą, Instytut Językoznawstwa Uniwersytetu im. Adama Mickiewicza w Poznaniu. 
wzorce zachowań. Ale może też propagować modele nowe, próbować pełnić funkcję wychowawczą, czy wręcz programującą, i w ten sposób ujawniać światopogląd postulowany. Wydaje się zatem, że można spojrzeć na ilustracje słownikowe jako na społeczne medium służące w szerszym kontekście do propagowania pewnych idei, wzorców społecznych, kulturowych norm.

\section{Podsumowanie}

Zasygnalizowane zagadnienia ogólne i kwestie szczegółowe nie zostały oczywiście omówione w sposób wyczerpujący, nie było to jednak celem niniejszego artykułu. Przywołano je tutaj jedynie jako argumenty mające potwierdzać słuszność założenia o możliwości i potrzebie rozpatrywania słowników obrazkowych dla dzieci w kontekście kulturowym, w odniesieniu do ich roli społecznej i edukacyjnej. Uwzględnienie wszystkich wspomnianych zagadnień pozwala przyjąć perspektywę badawczą, z której słowniki obrazkowe dla dzieci jawią się jako typ książki edukacyjnej, stanowiącej - poza prymarną funkcją rozwijania kompetencji językowych dziecka - swoiste medium pośredniczące w przekazywaniu kultury i kształtowaniu światopoglądu. Jako takie wymagają badań interdyscyplinarnych, uwzględniających perspektywę bibliologiczną, leksykograficzną, pedagogiczną oraz kulturoznawczą i socjologiczną.

Wynikający z przedstawionych $\mathrm{w}$ tekście założeń program badań słowników obrazkowych wykazuje zbieżność z wątkami refleksji nad książką obrazkową jako medium kulturowym i narzędziem edukacyjnym (zob. Cackowska 2017: 28-30). Stąd szukanie inspiracji oraz wsparcia teoretycznego i metodologicznego właśnie w obszarze badań nad książką obrazkową wydaje się najbardziej obiecujące. Z tego samego względu zasadne zdaje się włączenie badań nad słownikami obrazkowymi do pola badawczego książki obrazkowej.

Omawiane publikacje słownikowe spełniają swoje poznawcze zadania za pośrednictwem dwóch równorzędnych kodów - językowego i obrazowego, w związku z czym można mówić o polisemiotycznym charakterze ich treści. Warstwa werbalna (poprzez wybór i określone uporządkowanie słownictwa) staje się swoistym portretem konkretnego języka, natomiast warstwa obrazowa (zarówno poprzez swoją formę, jak i treść) portretem konkretnej kultury albo przynajmniej kręgu kulturowego. Co interesujące - portretem sporządzonym na potrzeby dziecięcego odbiorcy, a zatem dokumentującym pośrednio sposób postrzegania dziecka i dzieciństwa.

Obraz w słownikach dla dzieci okazuje się w tym kontekście bardzo ważnym nośnikiem treści. Komunikuje nie tylko o semantyce ilustrowanych słów. Encyklopedyczny ze swej natury obraz przekazuje wiedzę o świecie, a dokładniej mówiąc o konkretnej (pod względem chronologicznym i geograficznym) rzeczywistości kulturowej. Ilustracje sytuacyjne i kontekstowe, różnorodne scenki rodzajowe często całostronicowe - są pretekstem do zaznajomienia dziecka z konkretnym 
obszarem leksyki (polem leksykalnym), ale też - co szczególnie interesujące - przekazują treści o charakterze społecznym, wyraźnie zrelatywizowane kulturowo. Prezentują określoną wizję świata, kształtują wyobrażenia na temat obowiązujących norm i wzorców zachowań, ujawniają utrwalone społecznie konotacje i stereotypy. A same słowniki stają się szczególnym - często pierwszym, wszechstronnym i całościowym - książkowym przewodnikiem po otaczającej rzeczywistości społecznej i kulturowej.

\section{Literatura}

Anusiewicz J., 1991, Kulturowa teoria języka. Zarys problematyki, „Język a Kultura”, t. 1.

Anusiewicz J., 1994, Lingwistyka kulturowa. Zarys problematyki, Wrocław: Wydawnictwo Uniwersytetu Wrocławskiego.

Biesaga M., 2016, Pictorial Illustration in Dictionaries. The State of Theoretical Art [w:] Proceedings of the XVII EURALEX International Congress. Lexicography and Linguistic Diversity, eds T. Margalitadze, G. Meladze, Tbilisi: Ivane Javakhishvili Tbilisi State University.

Cackowska M., 2010, O pojęciu i pojmowaniu książki obrazkowej na świecie i w Polsce [w:] Przestrzenie teraźniejszości i ich społeczno-edukacyjne sensy, red. M. Szczepska-Pustkowska, M. Lewartowska-Zychowicz, A. Kożyczkowska, Toruń: Wydawnictwo Adam Marszałek.

Cackowska M., 2017, Współczesna ksiązka obrazkowa - pojęcie, typologia, badania, teorie, konteksty, dyskursy [w:] Książka obrazkowa. Wprowadzenie, red. M. Cackowska, H. Dymel-Trzebiatowska, J. Szyłak, Poznań: Instytut Kultury Popularnej.

Hallberg K., 2017, Literaturoznawstwo a badania nad ksiażka obrazkowa [w:] Książka obrazkowa. Wprowadzenie, red. M. Cackowska, H. Dymel-Trzebiatowska, J. Szyłak, Poznań: Instytut Kultury Popularnej.

Hojka B., 2008, Ilustracje w ogólnych stownikach języka polskiego: wprowadzenie, „Bibliotekoznawstwo", nr 27.

Hojka B., 2016, Poznawcze walory ilustracji w stownikach dla dzieci, „Bibliotheca Nostra”, nr 1 .

Hupka W., 1989, Wort und Bild: Die Illustrationen in Wörterbüchern und Enzyklopädien, Tübingen: Niemeyer.

Kopińska V., 2016, Krytyczna analiza dyskursu - podstawowe założenia, implikacje, zastosowanie, „Rocznik Andragogiczny”, nr 23.

Kümmerling-Meibauer B., Meibauer J., 2017, Pierwsze ilustracje, pierwsze koncepty: ksiażki wczesnokonceptowe [w:] Ksiażka obrazkowa. Wprowadzenie, red. M. Cackowska, H. Dymel-Trzebiatowska, J. Szyłak, Poznań: Instytut Kultury Popularnej.

Kwaśnicka-Janowicz A., 2008, Problemy zwiazane $z$ wprowadzaniem ilustracji do haset słownikowych [w:] Nowe studia leksykograficzne, t. 2, red. P. Żmigrodzki, R. Przybylska, Kraków: Wydawnictwo Lexis, https://ijp.pan.pl/images/publikacje_elektroniczne/ nsl_tom2/11kwasnicka.pdf [dostęp: 6.04.2018].

Lew R. et al., 2017, Competition of definition and pictorial illustration for dictionary users' attention: An eye-tracking study, „International Journal of Lexicography”, no. 31. 
Piekot T., Żurek A., 2008, Ideologie w podręcznikach do nauczania języka polskiego jako obcego [w: Ideologie w słowach i obrazach, red. I. Kamińska-Szmaj, T. Piekot, M. Poprawa, Wrocław: Wydawnictwo Uniwersytetu Wrocławskiego.

Piotrowski T., 1993, Słowniki języka polskiego [w:] Współczesny język polski, red. J. Bartmiński, Wrocław: „Wiedza o Kulturze”.

Siemieński T., 1991, Problematyka relacji między językiem a kultura w pracach językoznawców amerykańskich, „Język a Kultura”, t. 1.

Szczepaniak R., 2000, The Role of Illustrations in Explaining Meaning in Learner's Dictionaries, „Zeszyty Naukowe Uniwersytetu Opolskiego. Filologia Angielska”, nr 11.

Zając M., 2000, Promocja książki dziecięcej, Warszawa: Wydawnictwo SBP.

\section{Streszczenie}

W artykule omówiono wybrane problemy badawcze związane z obrazkowymi słownikami dla dzieci. Szczególny nacisk położono na zagadnienie roli obrazu w przekazywaniu treści o charakterze społecznym i kulturowym. Ilustracje zamieszczane w słowniku zawierają reprezentację znaczeń słów, a także wiedzę pozajęzykową - prezentują różne fragmenty rzeczywistości i wybrane obszary życia społecznego. Z tego względu mogą być badane jako medium kulturowe.

\section{Słowa kluczowe}

słownik obrazkowy, słownik dla dzieci, książka obrazkowa, ilustracja

\section{Summary}

Language and culture in pictures - about research issues pictorial dictionaries for children in a cultural context

The aim of the article is to present selected research issues related to pictorial dictionaries for children. The most important issue is the role of dictionary illustration in the transmission of social and cultural content. Illustrations published in dictionaries for children explain meaning of words, but also contain non-linguistic knowledge about environment and culture and so they can be considered as a cultural medium.

\section{Keywords}

picture dictionary, dictionary for kids, picturebook, illustration 
